\title{
Globalization and economic growth of Eurozone economies*
}

\author{
Marija Radulović ${ }^{1}$, Milan Kostić ${ }^{2}$
}

\begin{abstract}
Globalization is a process of world economic integration which leads to the global economy without borders. The paper estimates the impact of globalization on economic growth in the case of European Monetary Union countries (EMU). Authors used three components of globalization - economic, social, and political globalization. Pooled Mean Group estimator (PMG) was used to estimate the long-run and short-run relationship between globalization and economic growth. The results showed that in the short-run, economic and social globalization has a positive impact on economic growth, while political globalization has a negative effect on the economic growth of EMU countries. In the long-run, economic globalization has a statistically significant positive impact on the economic growth of EMU countries, while social and political globalization has a negative effect on the economic growth of EMU countries. Authors recommend, for each country, case by case approach in accepting the globalization process. The approach depends on the country's development stage, social, and political background. Thus, the approach for developing and least developed countries could be an evolutionary way, while for the developed ones a faster way of acceptances of globalization, for developed countries.
\end{abstract}

Key words: economic, political and social globalization, economic growth, monetary union, case by case approach

JEL classification: L62, L63, L68

\footnotetext{
Received: 27-08-2019; accepted: 10-04-2020

1 PhD student at University of Kragujevac, Faculty of Economics, Serbia. Scientific affiliation: national competitiveness, competition policy, market concentration, and foreign direct investment.E-mail: marijaradulovicvb@gmail.com.

2 Associate professorat University of Kragujevac, Faculty of Economics, Serbia. Scientific affiliation: microeconomics, industrial organization, competition policy and consumer ethnocentrism. E-mail: mkostic@kg.ac.rs,http://www.ekfak.kg.ac.rs/en/teaching-stuff?id=366\&idd=359.
} 


\section{Introduction}

Globalization is a term used very often and in different contexts. There is still no consensus about the globalization and its definition. Thus, different authors give different meanings of globalization. According to Waters (1995), globalization is social processes in which the geographical limitations on social and cultural events disappear, and in which people increasingly become aware of it. For Gilpin (2001) globalization represents the integration of the world economy, while Avinash (2000) defines globalization as the integration of national economies leading to the notion of a global economy without borders. Accordingly, globalization is a multi-dimensional process; it has not only an economic component but includes political, social, and many other issues. Globalization, as the process of integration of the world market, provides the possibility of economic growth. The increase in economic activities that goes beyond national borders leads to the rise in international trade and a rise in foreign direct investment (FDI), to rising capital market flows. Globalization encourages a stronger international division of labor and efficient allocation of savings, increasing labor productivity, and can affect citizens' living standards (Dimitrijević, 2016). Globalization has some negative influences on national economies, too. One of the main is increasing wealth inequality between countries.

The most important feature of the globalization process is the interdependence among the economies of the national states with the world economy. Countries around the world are linked to a multi-dimensional system of economic, social, and political relations. Depending on the significance and level of complexity of these connections, a particular national economy suffers positive and negative effects of general trends in the world economy. Therefore, regional integration, association and development process has accelerated the establishment and development of the globalization process. The basis for the creation and development of the globalization process is the free trade zone, the customs union, the economic union, the highest degree of economic cooperation, and then the political and cultural association. It is precisely in that sense essential to examine the impact of globalization on the economic growth of the European Monetary Union (EMU). The research problem is manifested in the vague effect of globalization on the economic growth of the European Monetary Union, primarily due to the lack of research dealing with this issue at EMU level, but also at the EU level. The aim of the paper was to determine the long-term and short-term impact of globalization components (economic, social, and political globalization) on economic growth within EMU countries.

Three hypotheses were tested in the paper. The first hypothesis of this paper is that economic globalization has a positive impact on economic growth in EMU countries. The second hypothesis is that social globalization has a positive impact 
on economic growth in EMU countries. The third hypothesis is that political globalization has a positive impact on economic growth in EMU countries. All of these hypotheses were tested for the short and long run. Therefore, there are additional hypotheses for the short and long run. As a result of testing hypotheses, the authors estimated the impact of all three components of globalization on the economic growth of EMU countries. This is one of the first papers which deals with the impact of globalization on the economic growth of this sample of countries, and that is the main contribution of the paper.

According to the aim and hypotheses of the research, the paper is structured as follows. Besides Introduction and Concluding remarks, there are four sections. Section two gives an overview of existing literature about the effects of globalization on economic growth. Section three represents methodology which has been used to estimate the impact of globalization on the economic growth of EMU countries. Section four shows empirical data and analysis, while section five shows results and discussion.

\section{Literature review}

In recent years, the issue of globalization effects has become a matter of interest among numerous researchers, but there is no consensus on the impact of globalization on economic growth. Dreher (2006) introduced a new index for measuring globalization called KOF. This index includes the analysis of three dimensions of globalization: (1) economic globalization, characterized as flows of goods, capital, and services, as well as the information and perception accompanying the market exchange; (2) political globalization, characterized by the diffusion of government policies and (3) social globalization, which is expressed as the dissemination of ideas, information, images, and people (ETH-Swiss Economic Institute, 2019). The constitution of the globalization index assumes that each of these variables is transformed into an index on a scale from one to a hundred, where a hundred is the maximum value for a specific variable which means the highest global integration level of some society. A detailed description of all dimensions of the KOF Globalization Index is given in Appendix (Appendix: Table 3). Dreher (2006) used the KOF index to study the impact of globalization on the economic growth of 123 countries from 1970 to 2000 using unbalanced panel data. The author concluded that there was a positive impact of the economic and social globalization on economic growth, but that the political globalization had no impact on economic growth. After Dreher introduced the KOF index of globalization, extensive research based on KOF has been conducted.

Afzal (2007) examined the impact of globalization on the economic growth of Pakistan from 1960 to 2006 using the error correction model for data analysis. As a 
proxy of the globalization, Afzal (2007) used financial integration and a trade gap and concluded that there is a long-term relationship between these variables. Shaikh and Shah (2008) also studied the effects of globalization on the economic growth of Pakistan and found that globalization has a positive impact on the economic growth of this country.

Bergh and Karlsson (2010) also examined the impact of globalization on economic growth from 1970 to 1995 and from 1970 to 2005, including 29 OECD countries. The KOF Globalization Index was used as an independent variable. They concluded that there was no statistically significant impact of this variable on the economic growth of the OECD countries. Chang and Lee (2010) have also studied the impact of globalization on the economic growth of OECD countries, but their results are opposed to the results obtained by Bergh and Karlsson (2010). They found a weak impact of globalization on economic growth in the short run. The authors found a strong effect of the overall KOF Globalization Index (especially economic and social globalization) on economic growth in the long run.

Villaverde and Maza (2011) studied the effects of globalization on economic growth using the overall KOF Globalization Index, the economic, social and political globalization as explanatory variables. They used GMM method to analyze data for 101 countries and concluded that the global KOF Globalization Index, economic, social, and political dimensions are positively related to economic growth. Rao and Vadlamannati (2011) used the KOF Globalization Index as an explanatory variable to test the impact of globalization on the economic growth of the 21 African countries from 1970 to 2005 . They found a statistically significant positive effect of globalization on economic growth. Rao et al. (2011) examined the impact of globalization on the economic growth of Malaysia, Thailand, India, and the Philippines. They found a positive effect of globalization on the economic growth of these countries.

Polasek and Sellner (2011) investigated the impact of globalization on the European Union's regional economic growth in 2006 using the model called Spatial ChowLin Procedure. They found the positive effects of globalization on the economic growth of the region. This is the only research that investigates the impact of globalization on the economic growth of the EU as an entity.

Mutascu and Fleischer (2011) investigated the impact of globalization on Romania's economic growth from 1972 to 2006. The Unrestricted Vector Autoregressive Model (Unrestricted VAR) was used for data analysis, and the results showed that globalization in the medium and long term positively affected Romanian economic growth. Açıkgöz and Mert (2011) investigated the impact of globalization on Turkey's economic growth from 1970 to 2008, analyzing the impact of political, economic, and social globalization. Autoregressive distributed lag model (ARDL) was used for data analysis. The results have shown that there is an impact of social and political 
globalization on economic growth, while there is no impact of economic globalization on Turkey's economic growth. Leitão (2012) analyzed the impact of globalization on the economic growth of the United States from 1995 to 2008. Using panel data analysis, the author found that globalization had a positive impact on the economic growth of the United States. Ray (2012) examined the impact of globalization on India's economic growth using the Granger causality test. The results showed that there is a two-way causality between economic growth and globalization.

Ali and Imai (2015) examined the impact of economic globalization on the economic growth of 41 African countries from 1970 to 2009. In addition, they questioned how the economic crisis affected economic growth. They used a panel analysis with the fixed-effects model and the GMM method for data analysis. Globalization was used as an endogenous variable. They concluded that economic globalization has a positive impact on economic growth. Furthermore, Umaru (2013) analyzed the impact of globalization on Nigeria's economic growth between 1962 and 2009, applying the Annual Average Growth Rate (AAGR) method. Umaru et al. (2013) found that globalization had a negative impact on the fuel, manufacturing industry, and stable mineral sectors, while globalization had a positive impact on agriculture, transport, and communication sectors. Samimi and Jenatabadi (2014) examined the impact of economic globalization on the economic growth of the countries of the Organization of Islamic Cooperation, testing whether this impact varies depending on the level of the country's income. Using the GMM method for data analysis, it has been found that there is a statistically significant impact of economic globalization on the economic growth of analyzed countries. They also found that the impact of economic globalization varies depending on the country's income level, primarily due to the development of the financial system and the education of the workforce.

Ying et al. (2014) dealt with the impact of political, economic, and social globalization on the economic growth of the ASEAN countries between 1970 and 2008 using the Folly Modified Ordinary Least Square (FMOLS) method. They found that economic globalization has a positive impact on economic growth, while social globalization has a negative impact on economic growth. Also, they found that there is no statistically significant influence of political globalization on economic growth. Suci et al. (2015) also analyzed the impact of globalization on the economic growth of Cambodia, Indonesia, Malaysia, Thailand, Philippines, and Vietnam (ASEAN) using panel data analysis. The overall KOF Globalization Index, political, social, and economic globalization were used as explanatory variables. They concluded that the overall KOF Globalization Index has a statistically significant positive impact on the economic growth of the observed countries, as well as economic and political globalization. They also found that there is no statistically significant impact of social globalization on economic growth. The results of Ying et al. (2014) and Suci et al. (2015) studies differ, although both 
studies were done for the ASEAN countries. Both studies have identified the positive impact of economic globalization on economic growth, while the results vary for the effects of social and political globalization.

Using the panel data analysis and fixed effects model, and Granger causality test, Kılıç (2015) examined the impact of economic, political, and social globalization on the economic growth of 74 developing countries between 1981 and 2011. The results of the panel analysis showed that there is a statistically significant positive impact of economics and political globalization on the economic growth of the analyzed developing countries, while the statistically significant negative effects of social globalization were found. The results of the Granger causality test have shown that there is a two-way causality between political globalization and economic growth and economic globalization and economic growth, while there is only a one-way causality between social globalization and economic growth.

Doğan and Can (2016) investigated the impact of globalization on the economic growth of South Korea from 1970 to 2012 using the Engel-Granger cointegration test. The overall KOF Globalization Index, social, and economic globalization are used as explanatory variables. The results of the research have shown that there is a statistically significant positive impact of KOF index, economic, and social globalization on the economic growth of South Korea. Reeshan and Hassan (2017) examined the effect of globalization, its social, political, and economic dimensions on economic growth in 86 developing countries in 2015, applying multiple regression. They have found that overall globalization (political, social, and economic globalization) has a negative and statistically non-significant impact on economic growth.

Based on all of the above, it can be concluded that there is a significant number of empirical research findings that confirm the impact of globalization on economic growth. The results of the research mentioned above on the effects of globalization on economic growth are different. However, in each study, a positive impact of at least one dimension of globalization on economic growth has been identified. The impact of economic globalization on economic growth is mainly positive, while this could not be the proper conclusion for the other two elements of the KOF index (social and political globalization). Results of research depend on different factors such as the research methodology, the research period, the sample and others.

\section{Methodology}

The aim of this study was to determine the effects of economic, political, and social globalization on the economic growth of Eurozone economies. Therefore, we analyzed annual data for 19 Eurozone economies (Austria, Belgium, Cyprus, 
Germany, Spain, Estonia, Finland, France, Greece, Ireland, Italy, Lithuania, Luxembourg, Latvia, Malta, Netherlands, Portugal, Slovakia, Slovenia) from 1970 to 2016. We focused on the estimation of the effects of the economic, social, and political dimension of globalization on economic growth, which has a good theoretical and empirical background (Kılıç, 2015; Ying et al., 2014; Mutascu and Fleischer, 2011; Reeshan and Hassan, 2017). Kilic (2015) and Ying et al. (2014) used only economic, social and political globalization as a measure of globalization and explanatory variables. Therefore, based on previous empirical researches, especially those done by Kılıç (2015) and Ying et al. (2014), a model was developed to estimate the impact of globalization on economic growth in the EMU countries. Authors used all three components of KOF, economic, social, and political globalization. The following equation set the model:

$$
\begin{aligned}
& G D P=\int(K O F E, K O F S, K O F P) \\
& G D P=b_{0}+b_{1} K O F E_{i t}++b_{2} K O F S_{i t}+b_{3} K O F P_{i t}+e_{i t} \\
& i=1, \ldots, 19 ; t=1970,2016
\end{aligned}
$$

Where GDP is GDP growth rate in $i$ EMU country in $t$ period, $K O F E_{i t}$ is the economic dimension of the KOF Globalization Index in $i$ EMU country in $t$ period, $K O F S_{i t}$ is the social dimension of the KOF Globalization Index in $i$ EMU country in $t$ period, and $K O F P_{i t}$ is the political dimension of the KOF Globalization Index in $i$ EMU country in $t$ period, $e_{i t}$ error term of $i$ country in $t$ period.

To investigate the impact of globalization on the economic growth of Eurozone economies, we first used descriptive statistics. After descriptive statistics, we used cross-section dependence test (Pesaran CD test) because the ignorance of the crosssection dependency leads to substantial bias in estimations. The stationarity of a time series implies that the time series moves along a recognizable path over time; that is, its properties remain unchanged over time (Mladenović, 2010). In time series, stationarity plays one of the very important roles, so it is necessary to test the existence of unit root. There are several unit-root tests in the literature examining the stationarity of time series. Still, the second generation of unit root test (CIPS cross-section Im, Pesaran, and Shin) was used to determine the order of integration of variables and to get unbiased estimations (Pesaran, 2007).

Panel analysis was used for econometric data analysis. Panel data represents data at multiple time points (in our case years) for multiple observation units (in our case, the countries). The nature of panel data, that is, both spatial and temporal dimensions, justifies their use in our research. Furthermore, previous researchers (Dreher, 2006; Leitão, 2012; Ali and Imai, 2015; Suci et al., 2015; Kılıç, 2015) also used panel data analysis, which can justify the use of panel analysis in our research. We distinguish between static and dynamic panel models. If the present 
value of a variable is influenced by its previous values, then we are talking about dynamic panel models. In dynamic panel models, the dependent variable shifts one or more periods backwards depending on its characteristics (lag dependent variable).

Auto-Regressive Distributed Lag (ARDL) approach was used for data analysis. To test whether the economic, political, and social globalization has a long-run and short-run impact on the economic growth within EMU the Pooled Mean Group (PMG) estimator by Pesaran et al. (1999) was used. The model uses the panel extension of the single equation autoregressive distributed lag (ARDL) model includes lagged dependent variable in the model and can also include lag for the independent variables (Krajišnik et al., 2019). Dynamic Fixed Effect (DFE) estimator also was tested. Hausman test was used to determine which estimator is more appropriate for accessing the long-run and short-run relationship between globalization and economic growth.

The following equation will be estimated:

$$
\begin{aligned}
& D G D P_{i t}=\alpha+\sum_{j=1}^{k} \beta_{j 2} D G D P_{i, t-j}+\sum_{j=0}^{k} \delta_{j 2} D K O F E_{i, t-j}+ \\
& +\sum_{j=0}^{k} \theta_{j 2} D K O F S_{i, t-j}+\sum_{j=0}^{k} \rho_{j 2} D K O F P_{i, t-j}+\gamma E C T_{i, t-j}+\varepsilon_{i t}
\end{aligned}
$$

Where $\beta_{\mathrm{j} 2}, \delta_{\mathrm{j} 2}, \theta_{\mathrm{j} 2}, \rho_{\mathrm{j} 2}$ are coefficients, $\varepsilon_{\mathrm{it}}$ is white noise term, $\gamma$ is the coefficient of the ECT (error-correction term). The coefficient $\gamma$ explains the long-term relationship between the variables presented in equation (4).

$$
\begin{aligned}
& E C T_{i, t-j}=G D P_{i t}-\alpha-\sum_{j=1}^{k} \beta_{j 1} G D P_{i, t-j}-\sum_{j=0}^{k} \delta_{j 1} K O F E_{i, t-j}- \\
& -\sum_{j=0}^{k} \theta_{j 1} K O F S_{i, t-j}-\sum_{j=0}^{k} \rho_{j 1} K O F P_{i, t-j}
\end{aligned}
$$

where $\beta_{j 1}, \delta_{j 1}, \theta_{j 1}, \rho_{j 1}$ are coefficients.

\section{Empirical data and analysis}

Annual series from ETH - Swiss Economic institute were used to measure economic, social, and political globalization of 19 Eurozone economies. Annual GDP growth rate series from the World Bank were used to measure the economic growth of Eurozone economies. Data and sources of data which were used in research are presented in Table 1. 
Marija Radulović, Milan Kostić • Globalization and economic growth of Eurozone...

Table 1: Sources of data

\begin{tabular}{|c|l|l|}
\hline Variable & \multicolumn{1}{|c|}{ Measure } & \multicolumn{1}{c|}{ Source } \\
\hline GDP & GDP growth rate $(\%)$ & World Bank \\
\hline KOFE & The economic dimension of globalization & ETH - Swiss Economic institute \\
\hline KOFS & The social dimension of globalization & ETH - Swiss Economic institute \\
\hline KOFP & The political dimension of globalization & ETH - Swiss Economic institute \\
\hline
\end{tabular}

Source: Authors'

Descriptive statistics of the observed variables are shown in Table 2. The average economic growth of EMU measured through GDP growth rate is $3.08 \%$, while the maximum GDP growth rate in the EMU countries was in Ireland in $2015(25.56 \%)$, and minimum GDP growth rate was in Lithuania in 2009 (-14.81\%) (Table 2). Lithuania has increasingly opened economically, socially, and politically since 1990 and after 2009. Still, total GDP and GDP per capita gains were relatively small due to the low baseline level, while Ireland is one of the most globalized economies and total GDP and GDP per capita gains due to globalization are high (Weiß et al., 2019). According to Masteikienea and Venckuvieneb (2015), Lithuania faces the harshest competition from global manufacturing competitors partially due to specific industry structure of the country. GDP growth rate in EMU for individual countries from 1970 to 2016 is given in Appendix (Figure 1).

Table 2: Descriptive statistics

\begin{tabular}{|l|c|c|c|c|}
\hline & GDP & KOFE & KOFS & KOFP \\
\hline Mean & 3.08 & 63.31 & 75.18 & 79.55 \\
\hline Median & 2.96 & 72.03 & 76.24 & 83.79 \\
\hline Maximum & 25.56 & 93.47 & 92.11 & 98.71 \\
\hline Minimum & 14.81 & 29.69 & 51.82 & 22.84 \\
\hline Standard deviation & 3.59 & 14.43 & 8.64 & 17.17 \\
\hline Number of observations & 757 & 757 & 757 & 757 \\
\hline
\end{tabular}

Source: Authors' calculations in EViews 10

The average economic globalization index in the EMU is 63.31, while the maximum economic globalization index was in Luxembourg in 2004 (93.47) and minimum economic globalization index was in Greece in 1970 (29.69). The average social globalization index in the EMU is 75.18. The maximum social globalization index was in Luxembourg in 2016 (92.11), while the minimum social globalization index was in Portugal in 1970 (51.82). It may be concluded that among the EMU countries, Luxembourg had the maximum value of economic and 
social globalization index. The average political globalization index in the EMU is 79.55. The maximum political globalization index was in France in 2009 (98.71), while the minimum political globalization index was in Estonia in 1991 (22.84) (Table 2). Figure 1 shows the average economic, social, and political globalization by Eurozone country.

Figure 1: The average economic, social, and political globalization by Eurozone country, (1970-2016)

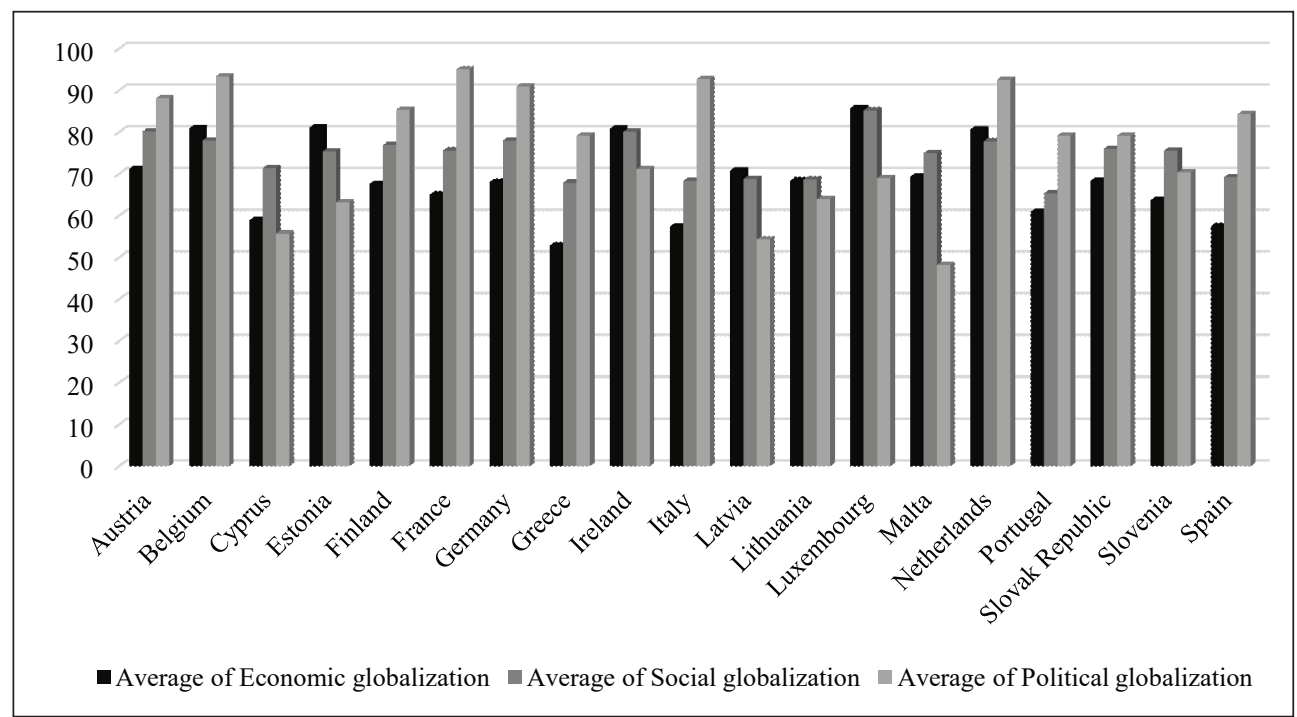

Source: Authors' calculations

Cross-section dependence test (Pesaran CD test) was used to analysethe null hypothesis that there is no cross-section dependence (correlation) in the time-series (Pesaran, 2004). It is important to test for the cross-sectional dependence in a panel analysis because the ignorance of the cross-section dependency leads to substantial bias in estimations. The results showed that there is a cross-section dependence in time series (Table 3). The results of cross-section dependence test (Pesaran CD test) showed that change of economic growth, economic, social, or political dimension of globalization that occurred in any of the observed EMU countries affected other countries as well. 
Marija Radulović, Milan Kostić • Globalization and economic growth of Eurozone...

Table 3: Results of cross-section dependence test

\begin{tabular}{|c|c|c|}
\hline Variable & t-statistic & p-value \\
\hline GDP & 41.04 & $0.00^{*}$ \\
\hline KOFE & 70.32 & $0.00^{*}$ \\
\hline KOFS & 75.96 & $0.00^{*}$ \\
\hline KOFP & 66.95 & $0.00^{*}$ \\
\hline
\end{tabular}

* indicate rejection of the null hypothesis at a $1 \%$ level of significance

Source: Authors' calculations in EViews 10

Since the results of Pesaran CD test showed that there is a cross-section dependence in all-time series, the second generation of unit root test (CIPS cross-section Im, Pesaran, and Shin) was used to determine the order of integration of variables and to get unbiased estimations (Pesaran, 2007). Results of the panel unit root test showed that the series are not integrated in the same order. Some series are stationary at the level I(0), while other series are stationary at the first difference I(1). GDP is stationary at the level I(0), while KOFE, KOFP, and KOFS are stationary at first difference. The results of the panel unit root test are shown in Table 4. Data for individual countries (at the level and first difference) for all variables are given in Appendix (Appendix: Figure 1-8).

Table 4: Results of unit root test

\begin{tabular}{|l|c|c|}
\hline \multicolumn{1}{|c|}{ Variable } & Intercept & Intercept and trend \\
\hline GDP & $-10.19^{*}$ & $-10.03^{*}$ \\
\hline KOFE & -0.44 & 3.37 \\
\hline D(KOFE) & $-13.06^{*}$ & $-12.45^{*}$ \\
\hline KOFS & 2.69 & 0.95 \\
\hline D(KOFS $)$ & $-14.42^{*}$ & $-14.01^{*}$ \\
\hline KOFP & $-2.66^{*}$ & $-2.32^{*}$ \\
\hline D(KOFP $)$ & $-11.69^{*}$ & $-10.60^{*}$ \\
\hline
\end{tabular}

* significant at $1 \%$ level

Source: Authors' calculations in EViews 10

Kao's test of cointegration was used to test the null hypothesis that there is no cointegration among variables (Kao \& Chiang, 2000). The results of Kao's test showed that there is cointegration among variables $(\mathrm{t}=-10.94, \mathrm{p}<0.01)$ at $1 \%$ significance level. Hausman test was used to determine whether the Pooled Mean Group estimator or Dynamic fixed effects model should be used for estimation. 
The results of the Hausman test showed that Pooled Mean group estimator is more appropriate for accessing the long-run and short-run relationship between globalization and economic growth $\left(\chi_{(3)}=0.56, \mathrm{p}=0.91\right)$. The Pooled Mean group estimations were obtained by estimating an $\operatorname{ARDL}(1,1,1,1)$ for all countries. The results of the Dynamic fixed effects model are presented in the Appendix (Table 4).

Table 5 shows the results of PMG estimates.

Table 5: PMG Results

\begin{tabular}{|l|c|c|c|c|}
\hline \multicolumn{1}{|c|}{ Variable } & Coefficient & Std. Error & t-statistics & p-value \\
\hline \multicolumn{5}{|c|}{ Long Run Equation } \\
\hline KOFE & 0.09 & 0.03 & 2.99 & 0.00 \\
\hline KOFS & -0.15 & 0.04 & -3.55 & 0.00 \\
\hline KOFP & -0.14 & 0.03 & -3.98 & 0.00 \\
\hline \multicolumn{5}{|c|}{ Short Run Equation } \\
\hline Cointeq1 & -0.68 & 0.05 & -13.85 & 0.00 \\
\hline D(KOFE) & 0.42 & 0.14 & 2.91 & 0.00 \\
\hline D(KOFS) & 0.69 & 0.17 & 4.17 & 0.00 \\
\hline D(KOFP) & -0.23 & 0.09 & -2.51 & 0.01 \\
\hline C & 12.18 & 1.07 & 11.37 & 0.00 \\
\hline
\end{tabular}

Source: Authors' calculations in EViews 10

Pooled mean group model results showed that there is a long-run and shortrun relationship between globalization and economic growth. In the long-run, economic, social, and political globalization have a statistically significant impact on economic growth within EMU (Table 5). Furthermore, economic globalization has a statistically significant positive impact on the economic growth of EMU, while social and political globalization has a statistically significant negative impact on the economic growth of EMU in the long run. The error correction term is negative and statistically significant, and shows that the speed of adjustment towards equilibrium is $68 \%$ annually (Table 5). It means that the system will be again in equilibrium for more than a year.

Short-run coefficients are also statistically significant and show that economic, political, and social globalization have a statistically significant impact on the economic growth of EMU countries. Equally to long-run, in the short-run, political globalization has a negative impact on economic growth and economic globalization has a positive statistically significant impact on the economic growth of EMU countries. However, social globalization has a positive and statistically significant impact on the economic growth of EMU countries in the short-run, 
while in the long-run, it has a negative impact on the economic growth of EMU countries (Table 5).

Short-run coefficients for individual countries were also examined. The results are shown in Table 6. The results for the individual countries of EMU showed that the error correction term is negative and statistically significant at $1 \%$ level in every country of EMU. According to results, the highest error correction term values are in Austria and Belgium (-0.99), Germany (-0.95) and Italy (-0.93) which means that these countries return to the equilibrium more quickly than other EMU countries, under the influence of economic, social, and political globalization. The lowest error correction term is in the case of Malta (-0.33), Lithuania (-0.33), and Spain $(-0.36)$ meaning that these countries return to the equilibrium slower than other EMU countries. It takes them about three years to return to equilibrium and correct disequilibrium created by the influence of economic, social, and political globalization.

Table 6: Short-run coefficients for individual countries

\begin{tabular}{|l|c|c|c|c|c|}
\hline \multicolumn{1}{|c|}{ Country } & Cointeq1 & $\mathrm{D}(\mathrm{KOFE})$ & $\mathrm{D}(\mathrm{KOFS})$ & $\mathrm{D}(\mathrm{KOFP})$ & $\mathrm{C}$ \\
\hline Austria & $-0.99^{*}$ & $0.17^{* *}$ & $0.88^{* *}$ & $0.12^{* *}$ & 19.22 \\
\hline Belgium & $-0.99^{*}$ & $0.51^{*}$ & $0.58^{* * *}$ & 0.01 & 18.69 \\
\hline Cyprus & $-0.71^{*}$ & 0.03 & $0.96^{* *}$ & $-0.07^{* * *}$ & 11.94 \\
\hline Germany & $-0.95^{*}$ & $0.20^{* *}$ & 0.18 & $0.18^{*}$ & 18.63 \\
\hline Spain & $-0.36^{*}$ & $0.12^{* *}$ & 0.28 & $-0.08^{* *}$ & 6.59 \\
\hline Estonia & $-0.64^{*}$ & 1.41 & 1.99 & -1.14 & 10.25 \\
\hline Finland & $-0.67^{*}$ & $0.20^{* *}$ & 0.81 & $0.41^{*}$ & 12.55 \\
\hline France & $-0.62^{*}$ & 0.03 & $0.41^{* *}$ & $-0.43^{*}$ & 12.49 \\
\hline Greece & $-0.54^{*}$ & $0.24 * *$ & 0.37 & 0.01 & 9.05 \\
\hline Ireland & $-0.59^{*}$ & 0.24 & $1.92^{* * *}$ & -0.19 & 10.57 \\
\hline Italy & $-0.93^{*}$ & 0.04 & $0.36^{* * *}$ & -0.18 & 17.67 \\
\hline Lithuania & $-0.33^{*}$ & $2.43^{*}$ & $2.57 *$ & $-1.43^{* *}$ & 2.63 \\
\hline Luxembourg & $-0.78^{*}$ & 0.12 & 0.28 & -0.01 & 13.85 \\
\hline Latvia & $-0.49^{*}$ & $1.14^{* *}$ & 0.62 & 0.01 & 6.62 \\
\hline Malta & $-0.33^{*}$ & -0.04 & -0.22 & -0.27 & 5.88 \\
\hline Netherlands & $-0.62^{*}$ & $0.36^{*}$ & -0.12 & $-0.10^{* * *}$ & 11.65 \\
\hline Portugal & $-0.76^{*}$ & -0.03 & $0.42^{* *}$ & $-0.26^{*}$ & 13.17 \\
\hline Slovakia & $-0.76^{*}$ & 0.07 & 0.61 & -0.07 & 14.66 \\
\hline Slovenia & $-0.87^{*}$ & $0.69^{*}$ & 0.28 & -0.10 & 15.19 \\
\hline & & & & & \\
\hline
\end{tabular}

* statistically significant at $1 \%$ level; ** statistically significant at $5 \%$ level; *** statistically significant at $10 \%$ level

Source: Authors' calculation in EViews 10 
Furthermore, if we observe short-run coefficients for individual countries of EMU, it may be concluded that economic globalization has a positive impact on the economic growth of all EMU countries, except Malta and Portugal where negative, but the statistically non-significant impact of economic globalization on economic growth were found. The strongest positive and statistically significant impact of economic globalization in short-run is in Lithuania (2.43), while the lowest positive and statistically significant impact of economic globalization in short-run is in Spain (0.12) (Table 6). Table 6 also showed the short-run coefficient for social globalization impact on economic growth for individual countries. The results showed that social globalization has a positive and statistically significant impact on economic growth in Austria, Cyprus, France, Lithuania (the strongest positive impact; 2.57) and Portugal, that is in line with results obtained for the panel data. The negative and statistically non-significant impact of social globalization on economic growth in the short run is in Malta and Netherlands. The positive and statistically significant impact of political globalization is in Austria (0.12), Germany (0.18), and Finland (0.41). The negative and statistically significant impact of political globalization on economic growth is in Spain, France, Lithuania, and Portugal, while the strongest negative impact of political globalization on economic growth is in Lithuania (-1.43) that is in line with results obtained for the panel data (Table 6).

Pairwise Dumitrescu-Hurlin (2012) test panel was used to determine whether there is a causal relationship between variables (Table 7).

Table 7: Dumitrescu Hurlin Panel Causality Test

\begin{tabular}{|l|c|c|c|}
\hline \multicolumn{1}{|c|}{ Null hypothesis } & W-stat. & Zbar-stat. & p-value \\
\hline KOFE does not homogeneously cause GDP & 3.35 & 2.18 & 0.03 \\
\hline GDP does not homogeneously cause KOFE & 1.96 & -0.37 & 0.71 \\
\hline KOFS does not homogeneously cause GDP & 4.99 & 5.21 & 0.00 \\
\hline GDP does not homogeneously cause KOFS & 1.79 & -0.67 & 0.50 \\
\hline KOFP does not homogeneously cause GDP & 5.09 & 5.38 & 0.00 \\
\hline GDP does not homogeneously cause KOFP & 1.87 & -0.54 & 0.59 \\
\hline
\end{tabular}

Source: Authors' calculation in EViews 10

The results showed that there is one-way causality running from economic globalization to economic growth, one-way causality running from social globalization to economic growth, and one-way causality running from political globalization to the economic growth in the EMU. There was no evidence of bidirectional causality between these variables. The results for one-way causality running from social globalization to economic growth are in line with the results obtained by Kılıç (2015). 


\section{Results and discussion}

Although the term globalization is one of the most commonly used terms in the contemporary theoretical and empirical literature, it is a term that is extremely difficult to define, as well as the effects it has on economic growth. Globalization is a process whose consequences go far beyond the economic sphere and is now the subject of various multidisciplinary research. Accordingly, Dreher (2006) defined the KOF Index of Globalization, which includes three dimensions: social, economic and political. The study uses these dimensions of globalization as explanatory variables to examine their effects on the economic growth of Eurozone economies.

The results of the analysis show that globalization has significant effects on the economic growth of Eurozone economies in the long-run and the short-run. Economic globalization has a positive and statistically significant impact on the economic growth of Eurozone economies in the long-run, while social and political globalization has a negative effect on economic growth in the long-run. In that case, we can accept hypothesis one $\left(\mathrm{H}_{1}\right)$ and reject two $\left(\mathrm{H}_{2}\right)$ and three $\left(\mathrm{H}_{3}\right)$ hypotheses for the long-run period. The obtained results in the long run, for the impact of economic globalization on economic growth, are in line with results presented by Dreher (2006), Kilıç (2015), Villaverde and Maza (2011), while the results obtained for the impact of political globalization on economic growth are opposed to results obtained by K1lıc (2015). The results obtained for the effect of social globalization on economic growth are in line with results presented by Kılıç (2015) and opposed to results obtained by Dreher (2006) who found a positive impact of social globalization.

Economic and social globalization has a positive and statistically significant impact on the economic growth of Eurozone economies in the short-run, while political globalization has a negative effect on economic growth in the long-run. The obtained results for the effect of social globalization on economic growth in the short-run are opposed to the results obtained in the long-run. In that case, we can accept hypotheses one and two $\left(\mathrm{H}_{1}\right.$ and $\left.\mathrm{H}_{2}\right)$ and reject hypothesis three $\left(\mathrm{H}_{3}\right)$ in the short-run period. Economic globalization captures the effect of variables such as of trade, FDI flows and stocks, so the positive effect of economic globalization on economic growth is expected. One of explanation for opposite results of social globalization in short and long period could be that in short-run countries have benefited from new ideas, information and people, but in long-run period ideas, information, and people leave these countries.

Political globalization is reflected in the rise of international institutions and associations that are united around common interests, such as the United Nations, the OECD, the World Trade Organization, International Monetary Fund, etc. It includes embassies in the country, membership in International organizations, and participation in UN Security Council Mission. The results showed a negative impact of political globalization on economic growth in the short-run and the long- 
run. The obtained results may be due to the scope of the obligations associated with international agreements and organizations (Kılıçarslan and Dumrul, 2018).

The error correction term showed that the system would be again in equilibrium for more than a year. If individual countries are observed, the error correction term is statistically significant and negative for all countries, but Malta, Lithuania and Spain return to the equilibrium slower than other EMU countries. These countries need about three years to correct disequilibrium created by the influence of economic, social, and political globalization. According to Weiß et al. (2019), Spain has integrated globally to a lesser extent than other countries since 1990, so that may be the reason for the obtained results, and lower gains from the globalization. The reasons for these results for Malta may be a high geopolitical risk, small domestic market, lack of natural resources, and policy uncertainty (Simonescu, 2016).

Contributions of the research could be in the next things. First of all, this research is the first of this type for EMU countries. Second, there is a positive impact of economic globalization on economic growth, which means that globalization is significant for economic growth, especially for developed countries such as EMU counties. This statement could be controversial for developing and least developed countries. Next thing is the negative impact of political globalization on economic growth, which means that political influence from abroad could negatively affect economic growth. Nowadays there are a lot of international political obligations which every country has. Those obligations can restrict the domestic decisionmaking process in every field, especially economic policy. The fourth thing is the estimation of the controversial impact of social globalization on economic growth in the short and long-run period. In the short-run, countries receive new ideas, information from abroad, but in long-run, they lose ideas, information, and people who are looking for a new opportunity in other countries.

Authors could recommend policymakers to be careful with driving globalization process in their countries, especially with a social component. The solution could be the case by case approach, where each country needs to have its way of acceptaning the globalization process. The approach depends on the country's development stage, social, and political background. One approach could be an evolutionary way for developing and least developed countries, while the other approach could be a faster way of the acceptance of the globalization process for developed countries.

\section{Conclusions}

The paper examined the impact of globalization (economic, political, and social) on the economic growth of 19 EMU countries and causality relationship between the variables using ARDL approach and pairwise Dumitrescu-Hurlin test from 1970 to 2016. 
The results showed that in the short-run, economic and social globalization had a positive statistically significant impact on the economic growth of EMU countries, while political globalization has a negative impact on the economic growth of these countries. In the long-run, economic globalization had a statistically significant positive impact on the economic growth of EMU countries, while social and political globalization had a statistically significant negative impact on the economic growth of EMU countries. Finally, the results of pairwise DumitrescuHurlin test showed one-way causality running from economic, social, and political globalization (separately) to the economic growth in the EMU countries.

Since the economic globalization includes trade, foreign direct investments, import barriers and taxes on international trade, the higher positive effects of the economic globalization on the economic growth of Eurozone economies can be achieved by reducing tax on international trade or import barriers, and by attracting more foreign direct investments. Governments should also change policies to social globalization as to have positive effects on economic growth, both in the long-run and in the short-run.

The research is related to the EMU countries which are developed. Therefore,, some further research should be related to the developing or least developed countries. In that case, researchers could compare the impact of globalization on these three types of countries and can test the results of the research. Of course, recommendations for further research could be including a wider sample of countries with different economic, social and economic background and a longer period of research. For EMU countries some new types of research could be focused on estimation impact of globalization on currency policy, potential fiscal integration, common industrial policy, etc. New extensive research into this area could result in findings that might challengethe results presented in the paper.

\section{References}

Açıkgöz, Ş., Mert, M. (2011) "Does Globalization Affect Economic Growth? Case of Turkey", 12th International Symposium on Econometrics, Operations Research and Statistics, Pamukkale University, Denizli, pp. 701-716.

Afzal, M. (2007) "The impact of globalization on Economic Growth of Pakistan", The Pakistan Development Review, Vol. 46, No. 4, pp. 723-734, https://doi. org/10.30541/v46i4iipp.723-734.

Ali, A., Imai K.S. (2015) "Crisis, Economic Integration and Growth Collapses in African Countries", Journal of African Economies, Vol. 24, No. 4, August 2015, pp. 471-501, https://doi.org/10.1093/jae/ejv010.

Avinash, J. (2000) Background to globalization. Mumbai: Center for Education and Documentation 
Bergh, A., Karlsson, M. (2010) "Government size and growth: Accounting for economic freedom and globalization", Public Choice, Vol. 142, No. 1, pp. 195213, doi: https://doi.org/10.1007/s11127-009-9484-1.

Chang, C. P., Lee, C. C. (2010) "Globalization and Economic Growth: A Political Economy Analysis for OECD Countries". Global Economic Review, Vol. 39, pp. 151-173, doi: https://doi.org/10.1080/1226508x.2010.483835.

Dimitrijević, M. M. (2016) Strane direktne investicije kao nosioci procesa globalizacije, doktorska disertacija, Ekonomski fakultet Univerziteta u Nišu.

Dogan, B., Can, M. (2018) The Relationship Between Globalization and Income Distribution: An Empirical Analysis in the Context of South Korea. IGI Global, pp. 20-45, https://doi.org/10.4018/978-1-5225-5787-6.ch002.

Dreher, A. (2006) "Does Globalization Affect Growth? Empirical Evidence from a new Index Globalization", Applied Economics, Vol. 38, No. 10, pp. 1091-1110, https://doi.org/10.1080/00036840500392078.

Dumitrescu, E. I., Hurlin, C. (2012) "Testing for Granger non-causality in heterogeneous panels", Economic Modelling, Vol. 29, No. 4, pp. 1450-1460, https://doi.org/10.1016/j.econmod.2012.02.014.

Gilpin, R., (2001) Global Political Economy: Understanding the international economic order, Princeton: Princeton University Press.

Kao, C., Chiang, M. H. (2000) "Estimation and inference of a cointegrated regression in panel data. Nonstationary Panels". Elsevier Science Inc., Vol. 15, pp. 179-222, https://doi.org/10.1016/s0731-9053(00)15007-8.

K1lıç, C. (2015) "Effects of globalization on economic growth: Panel data analysis for developing countries". Economic Insights-Trends and Challenges, Vol. 4, No. 67, pp. 1-11.

K1lıçarslan, Z. and Dumrul, J. (2018) "The Impact of Globalization on Economic Growth: Empirical Evidence from the Turkey". International Journal of Economics and Financial Issues, Vol. 8, No. 5, pp. 115-123.

Krajišnik, M., Gligorić, D. and Gojković, B. (2019) Effects of fiscal consolidation in Western Balkan Countries. Zbornik radova Ekonomskog fakulteta u Rijeci: časopis za ekonomsku teoriju i praksu, Vol. 37, No. 2, pp. 527-551.

KOF. (2019) ETH - Swiss Economic Institute, KOF Index of Globalization. Retrieved from www.kof.ethz.ch/en/forecasts-and-indicators/indicators/kofglobalisation-index.html.

Leitão, N. C. (2012) "Economic Growth, Globalization and Trade", Management Research and Practice, Vol. 4, No. 3, pp. 18-24.

Masteikienea, R., Venckuvieneb, V. (2015) "Changes of Economic Globalization Impacts on the Baltic States Business Environments". Procedia Economics and Finance, Vol. 26, pp. 1086-1094, https://doi.org/10.1016/s2212-5671(15) 00934-x. 
Mladenović, Z. (2010) Kointegracija. Retrieved from: www.avs.ekof.bg.ac.rs/ master\%20-\%20primenjena\%20analiza\%20vremenskih\%20serija/materijali/ Kointegracija- osnove12\%20.pdf, [Accessed: 01.09.2019] .

Mutascu, M., Fleischer, A. M. (2011) "Economic growth and globalization in Romania". World Applied Sciences Journal, Vol. 12, No. 10, pp. 1691-1697.

Pesaran, M. H. (2004) "General diagnostic tests for cross section dependence in panels", CESifo Working Papers, No.1233.

Pesaran, M.H. (2007) "A Simple Panel Unit Root Test in the Presence of CrossSection Dependence", Journal of Applied Econometrics, Vol. 22, No. 2, pp. 265-312, https://doi.org/10.1002/jae.951.

Pesaran, M. H., Shin, I. AND Smith, R. (1999) "Pooled mean group estimation of dynamic heterogeneous panels." Journal of the American Statistical Association, Vol. 94, pp. 621-634.

Polasek, W., Sellner, R. (2013) "Does Globalization Affect Regional Growth? Evidence for NUTS-2 Regions in EU-27", DANUBE: Law, Economics and Social Issues Review, Vol. 4, No. 1, pp. 23-65, https://doi.org/10.2478/danb2013-0002.

Rao, B. B., Vadlamannati, K. C. (2011) "Globalization and growth in the low income African countries with the extreme bounds analysis". Economic Modelling, Vol. 28, pp. 795-805, https://doi.org/10.1016/j.econmod.2010.10.009.

Rao, B. B., Tamazian, A., Vadlamannati, K. C. (2011) "Growth effects of a comprehensive measure of globalization with country-specific time series data". Applied Economics, Vol. 43, No. 5, pp. 551-568, https://doi.org/10.1080/ 00036840802534476.

Ray, S. (2012) "Globalization and Economic Growth in India: A Granger Causality Approach", Journal of Law, Policy and Globalization, Vol. 2, pp. 18-30.

Reeshan, A., Hassan, Z. (2017) "Impact of globalization on economic growth among developing countries". International Journal of Accounting \& Business Management, Vol. 5, No. 1, pp. 164-179.

Samimi, P., Jenatabadi, H.S. (2014) "Globalization and economic growth: Empirical evidence on the role of complementarities". Globalization and Economic Growth, Vol. 9, No. 4, pp. 1-7.

Shaikh, F. M., Shah, M. A. (2008) Impact of Globalization on Pakistan's Economy by Using CGE Model, International Conference on Applied Economics ICOAE, pp. 839-845.

Simonescu, M. (2016) "The relation between economic growth and foreign direct investment during the economic crisis in the European Union". Zbornik radova Ekonomskog fakulteta u Rijeci: časopis za ekonomsku teoriju i praksu, Vol. 34, No. 1, pp. 187-213, https://doi.org/10.18045/zbefri.2016.1.187. 
Suci, S., Asmara, A., Mulatsih, S. (2015) „The Impact of Globalization on Economic Growth in ASEAN". Bisnis \& Birokrasi Journal, Vol. 22, No. 2, pp. 79-87, https://doi.org/10.20476/jbb.v22i2.5696.

Umaru, A. Hamidu, A. \& Salihu, M. (2013) "Globalization and its Impact on the Performance of the Nigerian Economy". Interdisciplinary Journal of Research in Business, Vol. 2, pp. 1-16.

Villaverde, J., Maza, A. (2011) "Globalization, growth and convergence". World Economy, Vol. 34, No. 6, pp. 952-971, doi: https://doi.org/10.1111/j.1467-9701. 2011.01359.x.

Waters, M. (1995) Globalization. London: Routledge

Weiß, J., Sachs, A., Weinelt, H. (2019) 2018 Globalization Report Who Benefits Most from Globalization? Retrieved from www.bertelsmann-stiftung.de/ fileadmin/files/BSt/Publikationen/GrauePublikationen/MT_Globalization_ Report_2018.pdf [Accessed: 12.07.2019].

Ying, Y. H., Chang, K., Lee, C. H. (2014) "The impact of globalization on economic growth”. Romanian Journal of Economic Forecasting, Vol. 17, No. 2, pp. 25-34. 


\title{
Globalizacija i ekonomski rast ekonomija Eurozone
}

\author{
Marija Radulović ${ }^{1}$, Milan Kostic ${ }^{2}$
}

\begin{abstract}
Sažetak
Globalizacija je proces svjetske ekonomske integracije koji vodi do globalne ekonomije bez granica. U radu se procjenjuje utjecaj globalizacije na gospodarski rast u slučaju zemalja Europske monetarne unije (EMU). Autori su koristili tri komponente globalizacije - ekonomsku, socijalnu i političku globalizaciju. Pooled Mean Group estimator (PMG) korišten je za procjenu dugoročne i kratkoročne veze između globalizacije i ekonomskog rasta. Rezultati su pokazali da u kratkom roku ekonomska i socijalna globalizacija ima pozitivan utjecaj na gospodarski rast, dok politička globalizacija negativno utječe na ekonomski rast zemalja EMU. Ekonomska globalizacija dugoročno ima statistički značajan pozitivan utjecaj na ekonomski rast zemalja EMU, dok društvena i politička globalizacija negativno utječe na ekonomski rast zemalja EMU. Autori preporučuju, za svaku zemlju, pojedinačni pristup prilikom prihvaćanja globalizacijskog procesa. Pristup ovisi o fazi razvoja zemlje, socijalnoj i političkoj pozadini. Jedan bi pristup mogao biti evolucijski za zemlje u razvoju i najmanje razvijene zemlje. Drugi pristup bi mogao biti brži način prihvaćanja globalizacije za razvijene zemlje.
\end{abstract}

Ključne riječi: ekonomska, politička i društvena globalizacija, ekonomski rast, monetarna unija, pojedinačni pristup

JEL klasifikacija: L62, L63, L68

1 Doktorand, Univerzitet u Kragujevcu, Ekonomski fakultet, Srbija. Znanstveni interes: nacionalna konkurentnost, zaštita konkurencije, koncentracija na tržištu i izravna strana ulaganja.E-mail: marijaradulovicvb@gmail.com.

2 Izvanredni profesor, Univerzitet u Kragujevcu, Ekonomski fakultet, Srbija. Znanstveni interes: mikroekonomija, industrijska organizacija, politika zaštite konkurencije i potrošački etnocentrizam.E-mail:mkostic@kg.ac.rs,http://www.ekfak.kg.ac.rs/en/teaching-stuff?id=366\&idd=359. 


\section{Appendices}
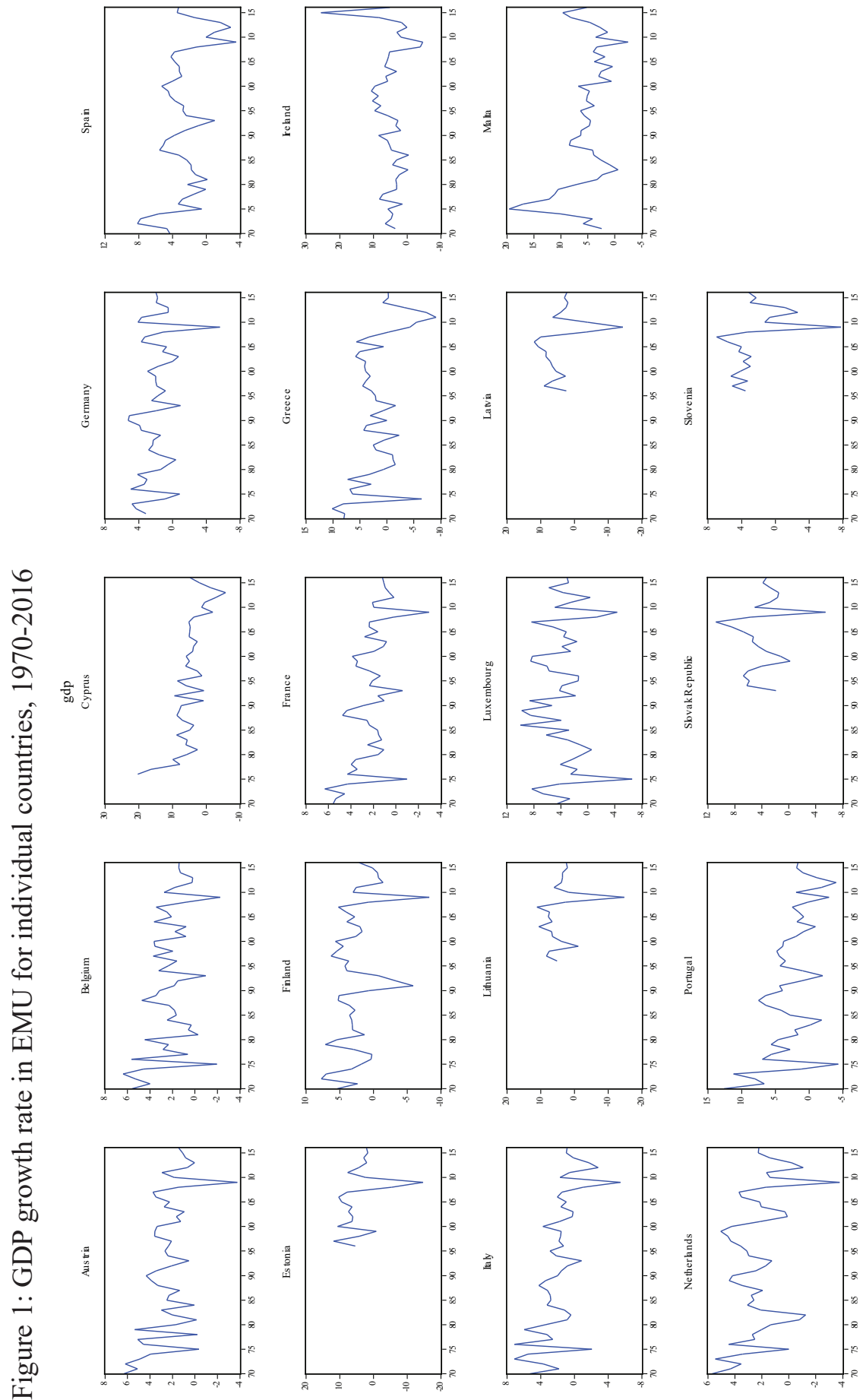

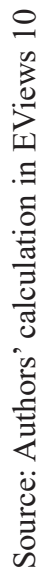


Marija Radulović, Milan Kostić • Globalization and economic growth of Eurozone...
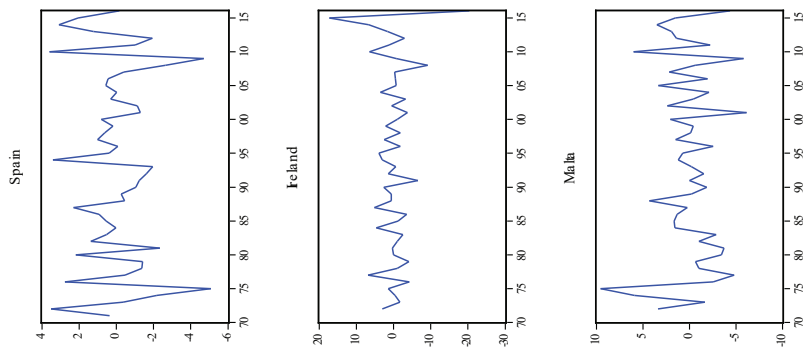

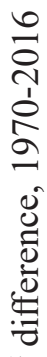
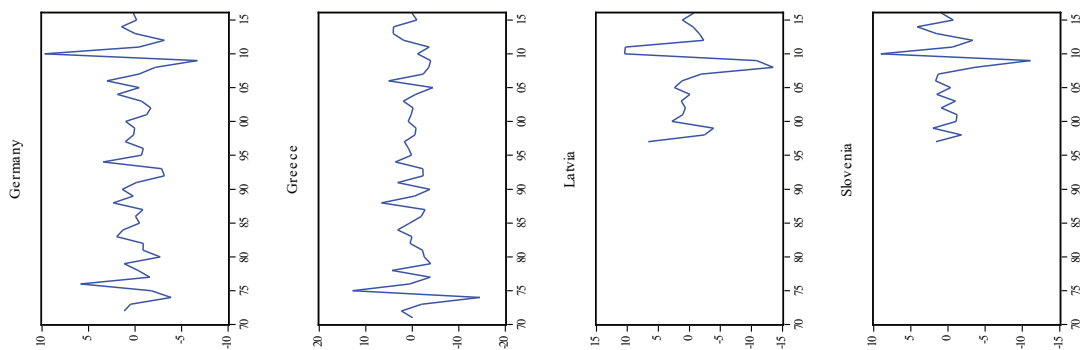

离
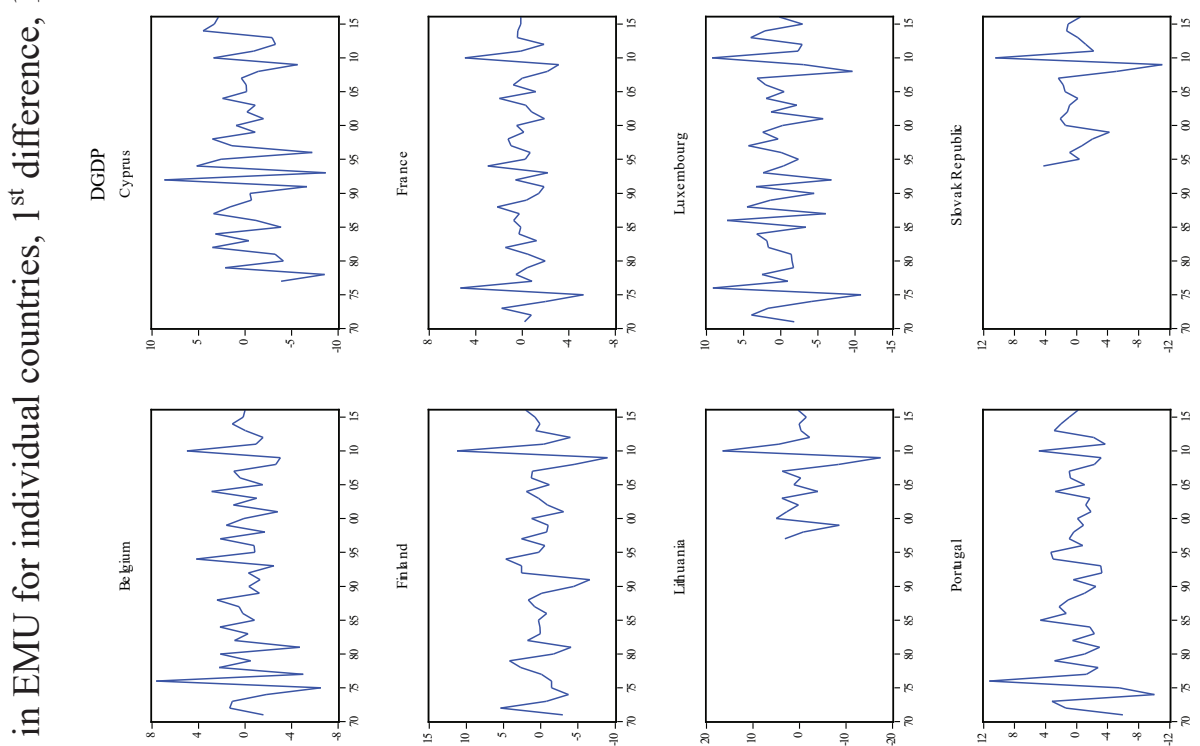

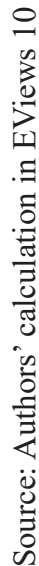



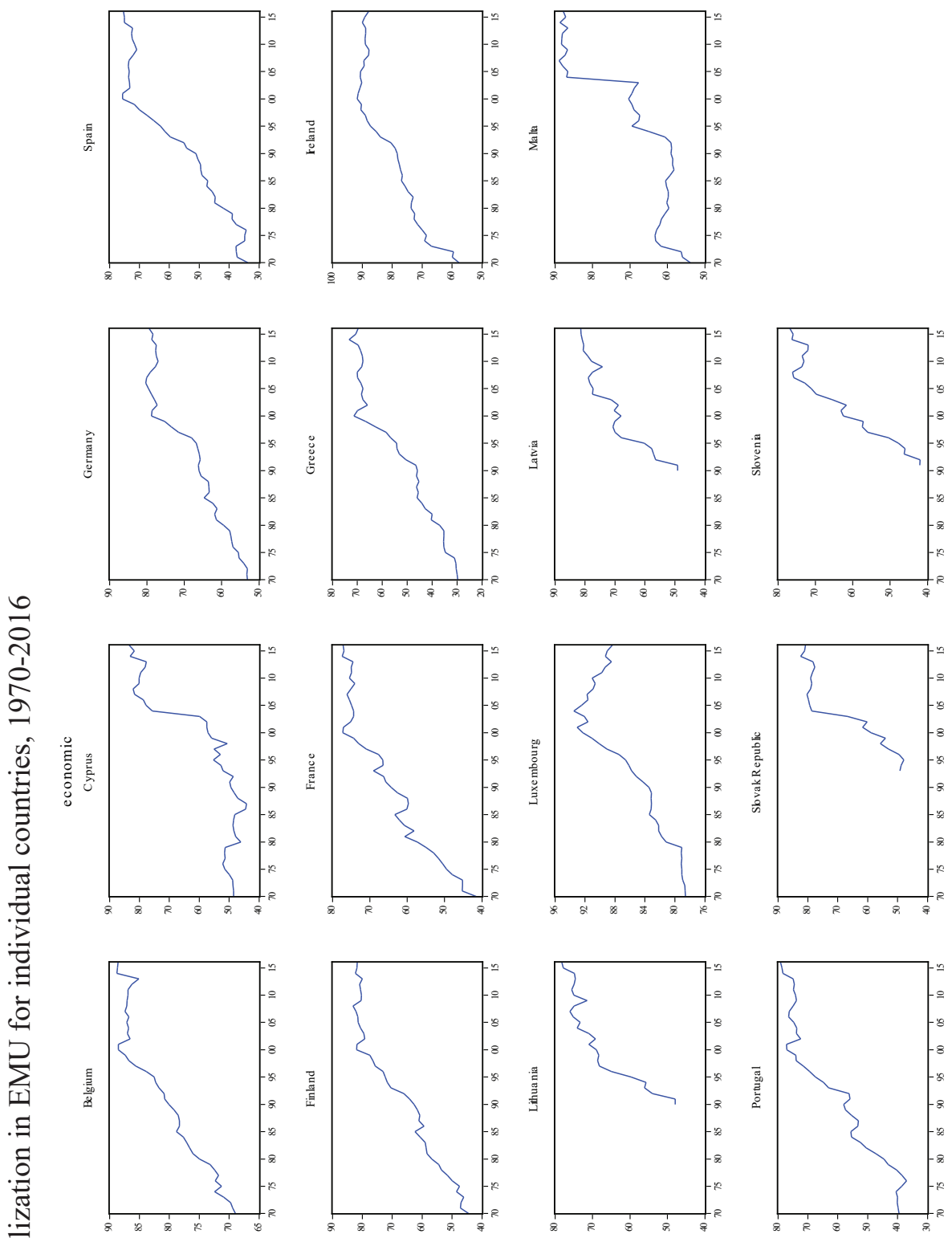

0
0
0
0
0
0
0
0
0
0
0
0
0
0
0
0
0
0
0
0
0
0
0 
Marija Radulović, Milan Kostić • Globalization and economic growth of Eurozone...
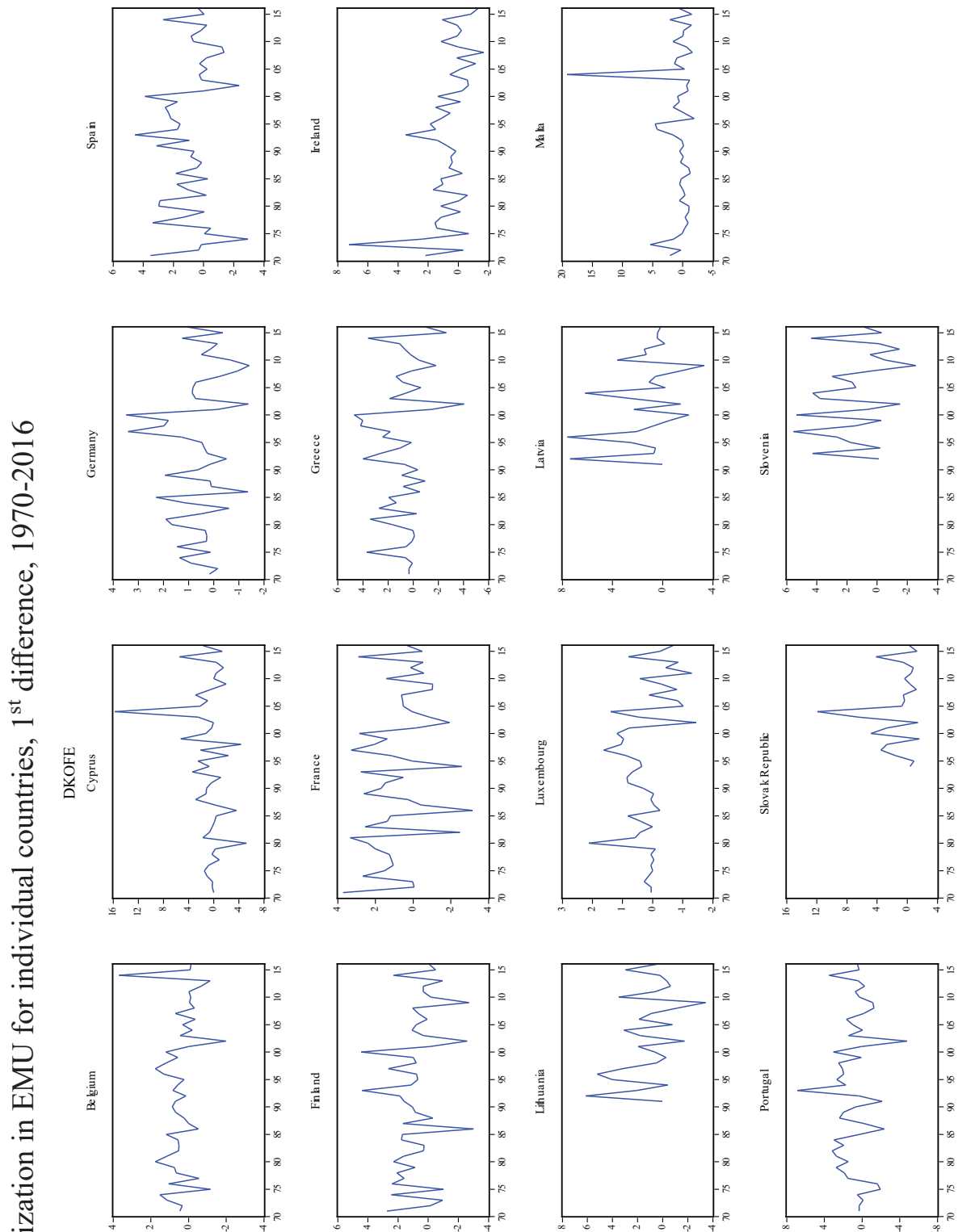

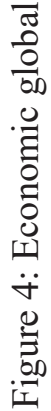
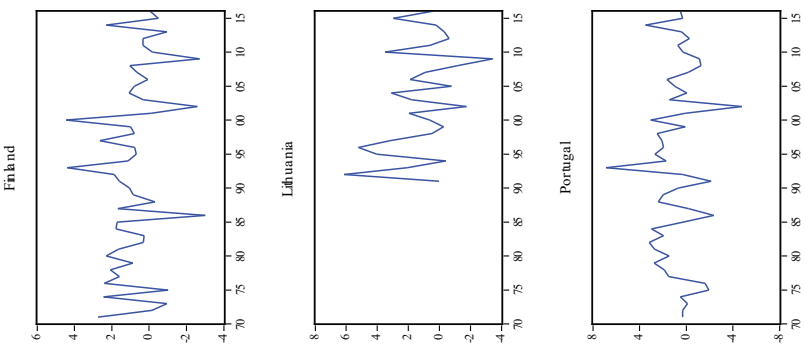

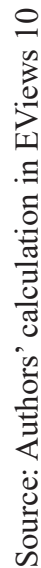



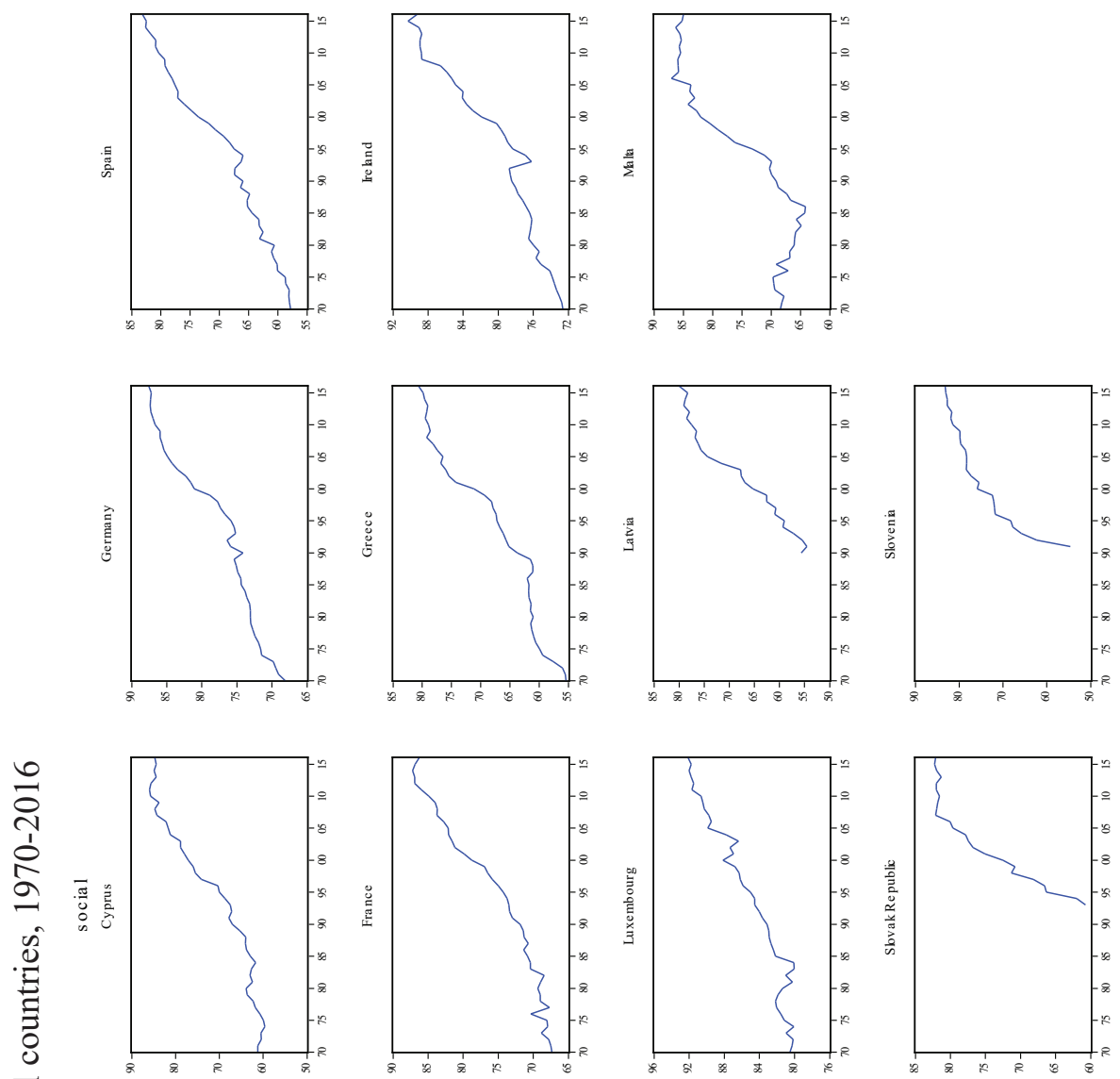

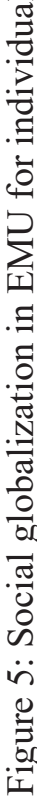
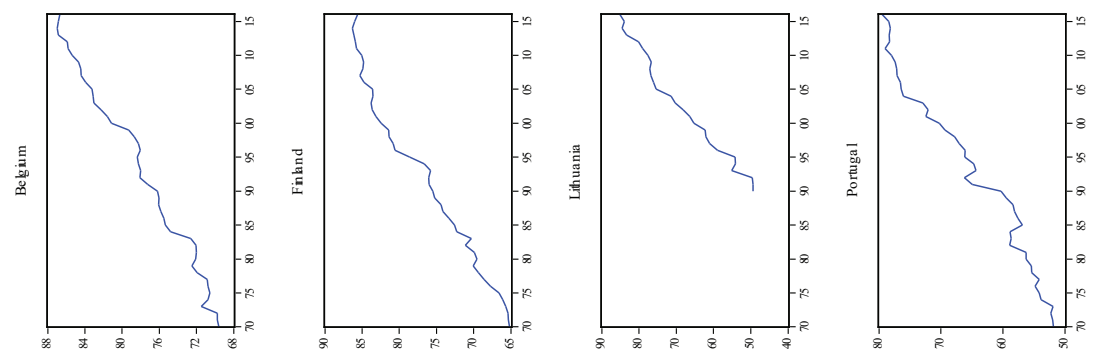

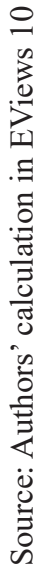


Marija Radulović, Milan Kostić • Globalization and economic growth of Eurozone...
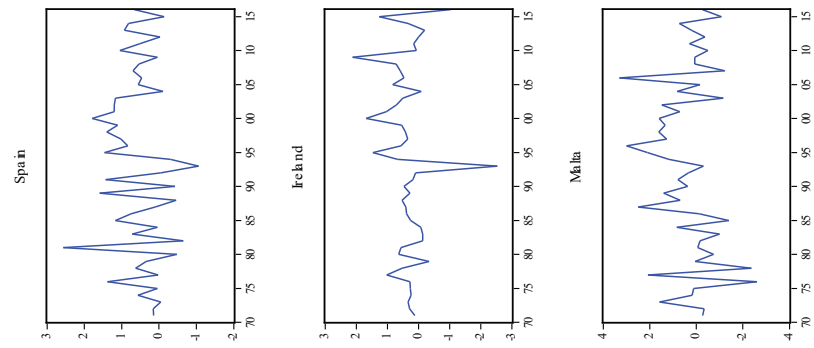

$\frac{6}{8}$
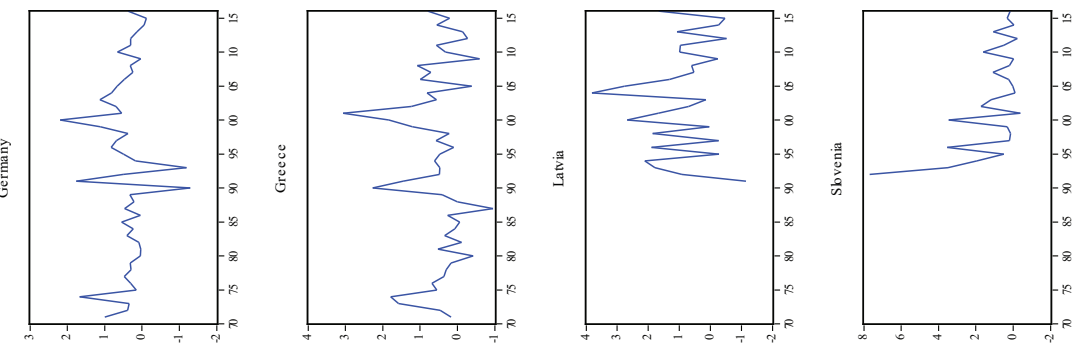

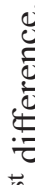
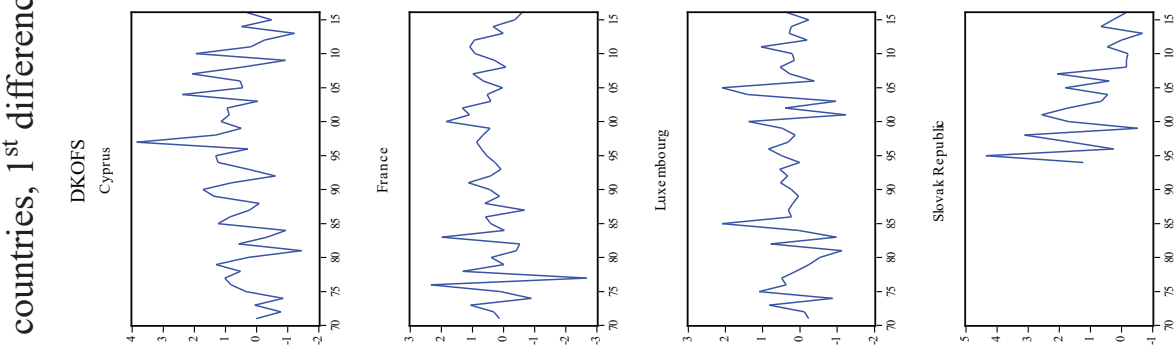

을
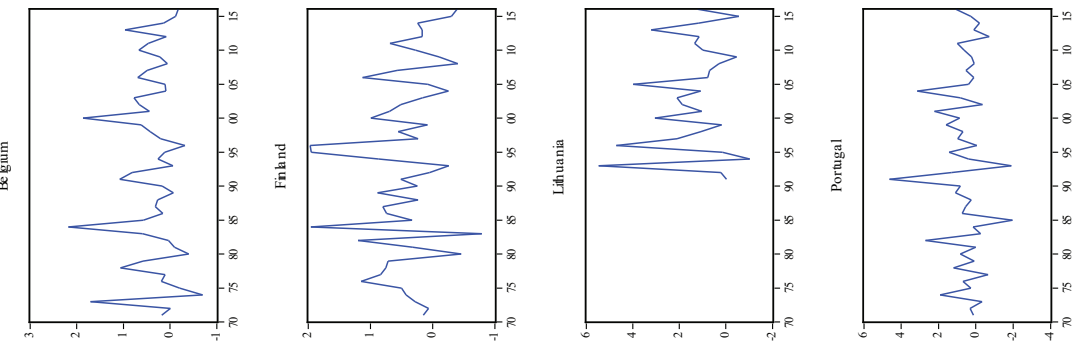

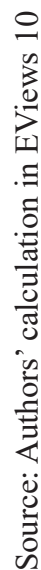



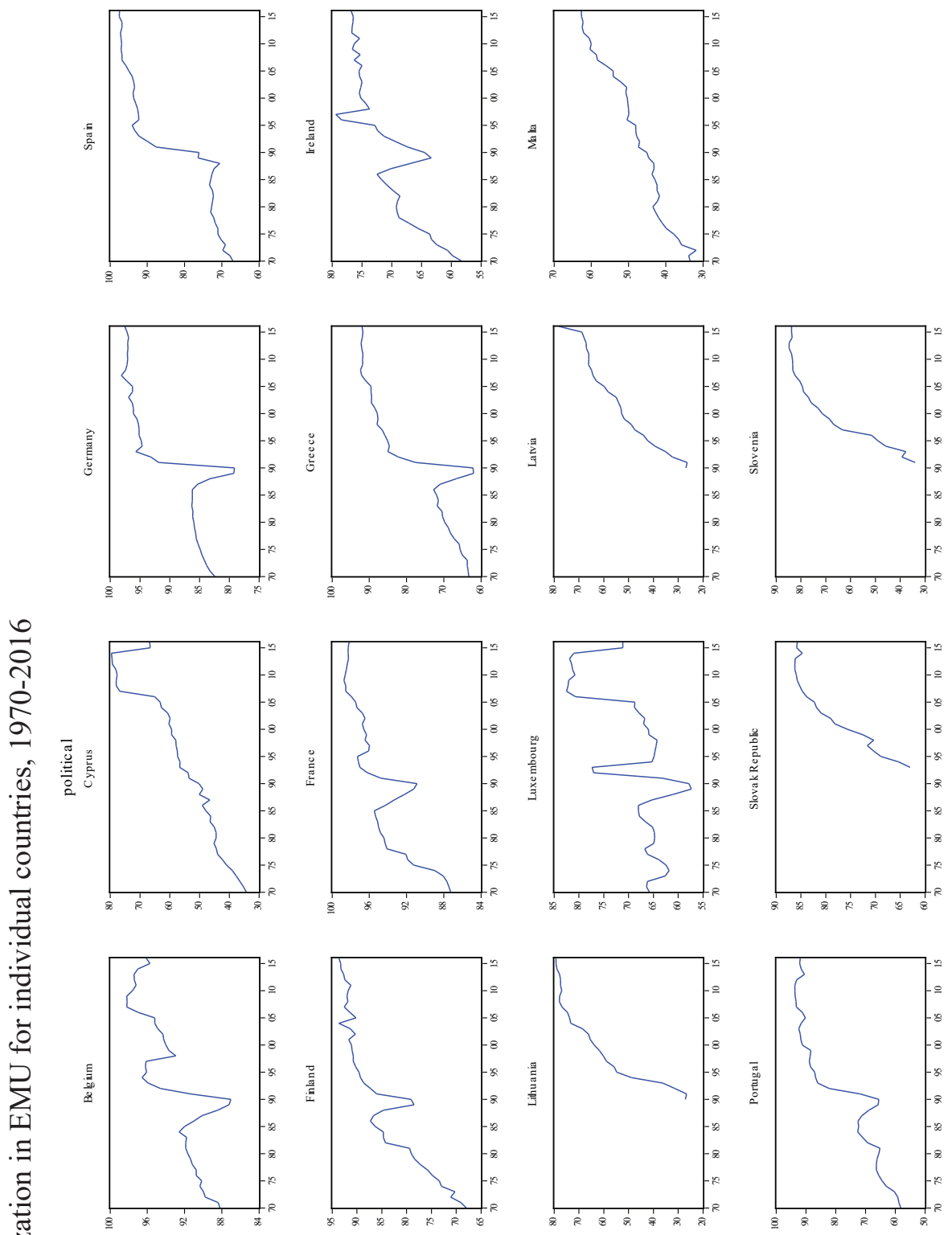

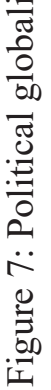
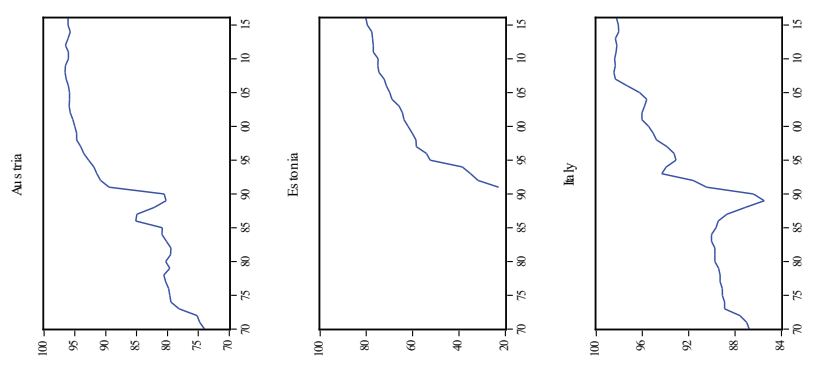

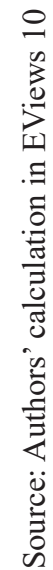


Marija Radulović, Milan Kostić • Globalization and economic growth of Eurozone...
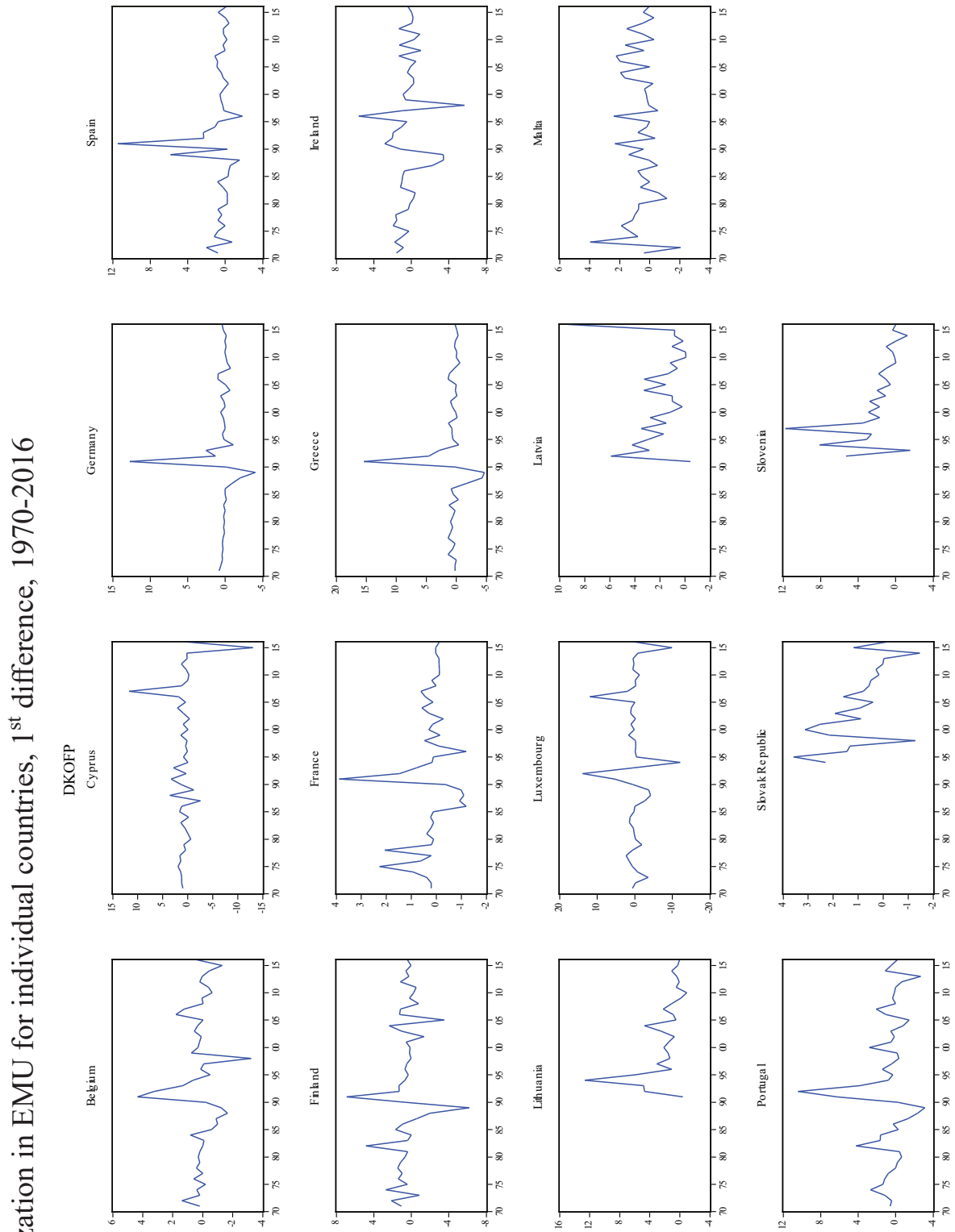

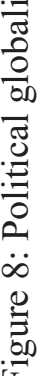
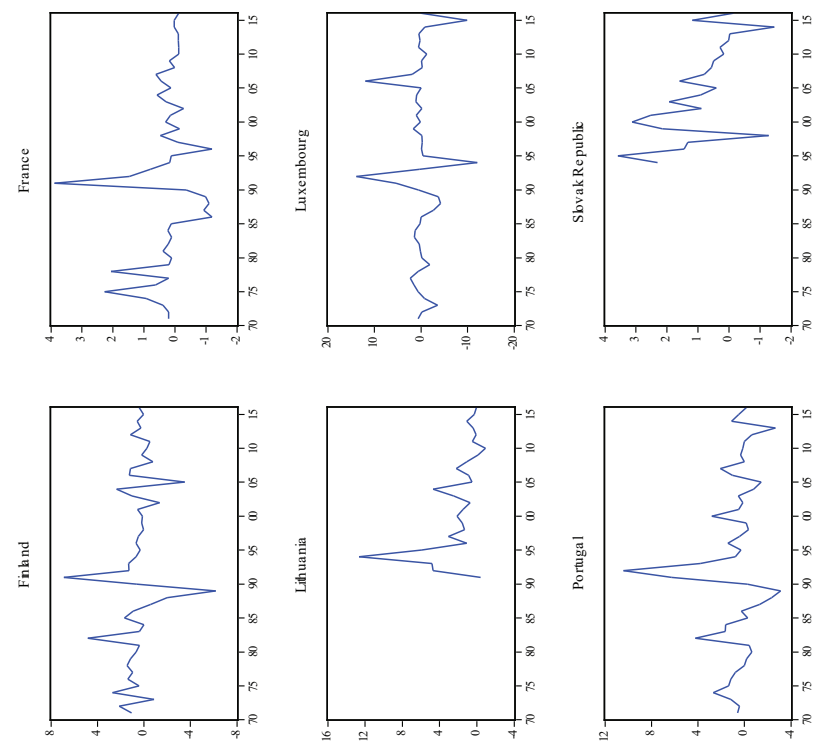

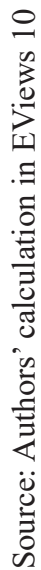


Table 1: Descriptive statistics for GDP for individual countries, 1970-2016

\begin{tabular}{|l|c|c|c|}
\hline \multicolumn{1}{|c|}{ Country } & Mean & Minimum & Maximum \\
\hline Austria & 2.42 & -3.76 & 6.32 \\
Belgium & 2.24 & -2.25 & 6.38 \\
Cyprus & 4.85 & -5.80 & 20.27 \\
Germany & 2.00 & -5.62 & 5.26 \\
Spain & 2.62 & -3.57 & 8.15 \\
Estonia & 4.15 & -14.72 & 11.80 \\
Finland & 2.52 & -8.27 & 7.74 \\
France & 2.26 & -2.94 & 6.31 \\
Greece & 1.82 & -9.13 & 10.16 \\
Ireland & 5.00 & -4.63 & 25.56 \\
Italy & 1.82 & -5.48 & 7.13 \\
Lithuania & 4.33 & -14.81 & 11.09 \\
Luxembourg & 3.75 & -6.57 & 9.98 \\
Latvia & 4.13 & -14.40 & 11.89 \\
Malta & 5.32 & -2.46 & 19.56 \\
Netherlands & 2.35 & -3.77 & 5.69 \\
Portugal & 2.72 & -4.35 & 12.61 \\
Slovakia & 4.06 & -5.42 & 10.80 \\
Slovenia & 2.60 & -7.80 & 6.94 \\
\hline
\end{tabular}

Source: Authors' calculation in EViews 10

Table 2: Descriptive statistics for economic globalization for individual countries, 1970-2016

\begin{tabular}{|l|c|c|c|}
\hline \multicolumn{1}{|c|}{ Country } & Mean & Minimum & Maximum \\
\hline Austria & 71.21 & 54.11 & 84.05 \\
Belgium & 80.93 & 68.97 & 88.77 \\
Cyprus & 58.88 & 44.22 & 83.42 \\
Germany & 68.10 & 53.13 & 80.31 \\
Spain & 57.52 & 33.74 & 75.58 \\
Estonia & 81.10 & 60.43 & 86.27 \\
Finland & 67.61 & 44.46 & 83.12 \\
France & 65.06 & 41.54 & 77.36 \\
Greece & 52.88 & 29.70 & 73.31 \\
Ireland & 80.86 & 57.70 & 91.66 \\
Italy & 57.42 & 41.41 & 72.68 \\
Lithuania & 68.41 & 47.89 & 78.18 \\
Luxembourg & 85.73 & 78.58 & 93.47 \\
Latvia & 70.82 & 49.05 & 81.44 \\
Malta & 69.30 & 53.86 & 88.91 \\
Netherlands & 80.66 & 66.34 & 89.01 \\
Portugal & 60.88 & 36.95 & 79.19 \\
Slovakia & 68.32 & 47.94 & 82.41 \\
Slovenia & 64.34 & 41.95 & 80.84 \\
\hline
\end{tabular}

Source: Authors' calculation in EViews 10 
Table 3: KOF Globalization Index and Its Dimensions

\begin{tabular}{|c|c|}
\hline Indices and variables & Weights \\
\hline 1. Economic globalization & $37 \%$ \\
\hline 1.1. Actual Flows & $50 \%$ \\
\hline Trade $(\%$ of GDP) & $18 \%$ \\
\hline FDI flows ( $\%$ of GDP) & $21 \%$ \\
\hline FDI stocks ( $\%$ of GDP) & $22 \%$ \\
\hline Portfolio Investment ( $\%$ of GDP) & $19 \%$ \\
\hline Income paid to foreign nationals ( $\%$ of GDP) & $20 \%$ \\
\hline 1.2. Restrictions & $50 \%$ \\
\hline Hidden import barriers & $24 \%$ \\
\hline Mean tariff rate & $28 \%$ \\
\hline Taxes on International trade ( $\%$ of current revenue) & $27 \%$ \\
\hline Capital account restrictions & $20 \%$ \\
\hline 2. Social globalization & $39 \%$ \\
\hline 2.1. Data on personal contact & $30 \%$ \\
\hline Telephone traffic ( $\%$ of GDP) & $13 \%$ \\
\hline Transfers $(\%$ of GDP) & $6 \%$ \\
\hline International tourism ( $\%$ of the total population) & $28 \%$ \\
\hline Foreign population ( $\%$ of the total population) & $26 \%$ \\
\hline International letters (per capita) & $28 \%$ \\
\hline 2.2. Data on information flows & $35 \%$ \\
\hline Internet users (per 1000 people) & $25 \%$ \\
\hline Television (per 1000 people) & $25 \%$ \\
\hline Trade-in newspapers ( $\%$ of GDP) & $21 \%$ \\
\hline Radio (per 1000 people) & $29 \%$ \\
\hline 2.3. Data on cultural proximity & $35 \%$ \\
\hline Number of McDonald's restaurants (per capita) & $40 \%$ \\
\hline Number of Ikea stores (per capita) & $41 \%$ \\
\hline Trade-in books ( $\%$ of GDP) & $19 \%$ \\
\hline 3. Political globalization & $25 \%$ \\
\hline Embassies in the country & $35 \%$ \\
\hline Membership in International organizations & $36 \%$ \\
\hline Participation in UN Security Council Mission & $29 \%$ \\
\hline
\end{tabular}

Source: Pekarskiene, I. \& Susniene, R. (2011), p. 62. 
Table 4: Dynamic fixed effects model results

\begin{tabular}{|l|c|c|c|c|}
\hline \multicolumn{1}{|c|}{ Variable } & Coefficient & Std. Error & t-statistics & p-value \\
\hline \multicolumn{5}{|c|}{ Long Run Equation } \\
\hline KOFE & 0.16 & 0.04 & 3.90 & 0.00 \\
\hline KOFS & -0.20 & 0.06 & -3.21 & 0.00 \\
\hline KOFP & -0.18 & 0.05 & -3.72 & 0.00 \\
\hline \multicolumn{5}{|c|}{ Short Run Equation } \\
\hline Cointeq1 & -0.65 & 0.03 & -19.24 & 0.00 \\
\hline D(KOFE) & 0.14 & 0.06 & 2.41 & 0.02 \\
\hline D(KOFS) & 0.59 & 0.13 & 4.57 & 0.00 \\
\hline D(KOFP) & -0.05 & 0.06 & -0.90 & 0.37 \\
\hline C & 13.08 & 1.74 & 7.52 & 0.00 \\
\hline
\end{tabular}

Source: Authors' calculations in Stata 14 